\title{
The fair use and statutory license of the works in university library
}

\author{
Mei Dai \\ LinYi University Library, Shan Dong, China \\ daimei@lyu.edu.cn
}

Keywords: Library; Protecting; Works; Fair Use; Statutory License; Compulsory License.

\begin{abstract}
In order to safeguard the overall interests of society and the legal dissemination and application of science and technology, restrictions are imposed on effectiveness and scope of intellectual property enforcement in Copyright Law. In the paper, we discussed that the main restrictions which are fair use, statutory license, compulsory license. The paper introduced the function of university library in protecting the creation and the dissemination of works, and discussed that how to apply copyright law to realize fair use, statutory license and compulsory license of the works.
\end{abstract}

\section{The characteristics of library in universities}

As a special type of library,university libraries have many distinctive characteristics: It has specific functions,mainly to protect the foundation of works and to support education and learning; the scope of spreading works's limition is in the campus; the purpose of contacting and using these works is learning. [1]

\section{The foundation of protecting the creation of works and spreading in university libraries}

Library in universities play an important role in protecting the creation of works and spreading,and they're used to serve the students and teachers with collecting and sorting all kinds of data and information in accordance with the need of education and scientific researsh. They're the central of the literature data in the university,the treasure house of knowledge, and they're also the cultural construction base of spreading advanced culture of Marxism Leninism,Mao Zedong Thought,Deng Xiaoping Theory,three represents,constructing scientific development view and the spirit of the 18th National Congress of the Communist Party of China.Library in universities are thoughtout spreading the most excellent works to all the students and teachers. Though the way of spreading works may not so widely like social libraries, what they are affecting is thousands of educated youth with lofty ideals that mainly become the main force during the constructing of the motherland's modernization. With the develpoment of modern economy,we do need lots of great works and cultures to enrich our inner world,so the library plays a more and more important role as the second classroom of quality education.The Copyright Law[2] encourages and protect the creation and spreading of wonderful works, which the principle is in line with the library's guildline of protecting and spreading the creation of works.

\section{The restrictions of fair use which should be paid attention on when university libraries protecting the creation of works and spreading}

Fair use is an institution that law can permit everyone to use the copyright freely under a special circumstance that it's not necessary to get the agreement of the copyright owner neither should they pay for that.According to concerned regulations of the Copyright Law,article 22 points that the fair use should have three conditions:The works you use should be published,and the use of unpublished works is out of the scope of fair use. The aim of using should be limited to ptivate study,research and learning,or for the needs of education,scientific research,religion,charity or for the interests of public 
culture; it's forbidden to invade the copyright owner's other rights and you must specific the author's name and the title of the work. [3]

The scope of fair use. It is stipulated in article 22 of the Copyright Law that a work may be used without permission and without payment to the copyright owner,but the name of the author and the title of the work should be indicated and the other rights enjoyed by the copyright owner by virtue of this Law should not be prejudiced.There are several regulations which are closely related to the fair use of the works in university library:

use of a published work of others for the user's own private study, research or self entertainment,

appropriate quotation from a published work of others in one's work for the purposes of introduction to, or comment on, a work, or demonstration of a point,

translation or reproduction in a small quantity of copies, of a published work for use by teachers or scientific researchers, in classroom teaching or scientific research, provided that the translation or reproduction shall not be published or distributed,

reproduction of a work in its collections by a library, an archives center, a memorial hall,a museum,an art gallery or a similar institution, for the purposes of display,or preservation of a copy,of the work,

translate a citizen, a legal person or any other organization's published works in the language of the Han nationality into minority nationality languages for publication and distribution in the country,

transliteration of a published work into Braille and publication of the work so transliterated.

These regulations do provide legal basis for the conservation of the creation of works and spreading in libraries.We can use fully of these restrictions to try our best to create a great atmosphere full of respect of knowledge,rights and vitality,so it also encourages people to read and study in libraries.

Two problems can easily be neglected in the process of fair use of libraries. The regulations in the Copyright Law[1] as stated in the former article,fair use should have three conditions, which should be taken comprehensive consideration when judging the rationality of others' action so these three conditions are connected inseparably.But in some conditions there seems to have exceptions.For example,some universities reprint thousands of books of other's published works for education and learning and seld them to students and teachers in the campus as cost price.Though the reprinter didn't seek profits at all,and the author's name and the source of the works were fully being respected,and the most important point of these behaviors is for the private interests, the behavior of large-scale copying does have an impact on the author and the sales market of the publishing house undoubtedly,so it's quite difficult to assert whether it's fair use or not.This is one of the two questions may be neglected.

Protecting the author's rights is the starting point and basic point of library daily work, because both in learning research and in protecting the author's property right of authors and the work personal rights. [4] What works we are talking about are published works, then what about graduation thesis and dissertation?Are they protected by the Copyright Law[1]?Are they being in the scope of fair use?The author holds that these two types of papers are intellectual achievement full of author's industriousness and hard working and they ought to be protected by the Copyright Law whether the works are publisded or not. [5] The work personal rights should be respected first.Some unpublished works contain the secret of author's creation or privacy and these should be respected by law.But as we all know that digital network is widely used in modern libraries,thousands of graduation thesis and dissertation are stored in the electronic reading room of library to help students and teachers to reference and learn, to research and utilize.So under this circumstance it's quite important to protect the work personal rights and right of internet communication rights. [6] That's a another question may be neglected in library daily work. 


\section{University libraries should pay attention on the restriction of statutory license when protecting the creation of works and spreading[7]}

As definitely regulated in the copyright law,legal permission refers to the right to use published works with copyright in a particular manner without the permission from the owner of the copyright,but the owner must be rewarded with certain amount of payment and his correlated rights be respected and protected according to the copyright law.

The scope of statutory license. The Copyright Law regulates seven circumstances of statutory license in Article 23,32,37,40,41,42 and 43.

Article 23 In compiling and publishing textbooks for the nine-year compulsory education and the state educational program, passages of published works, short writings works, music works or single copies of painting works or photographic works may be compiled into the textbooks without the license of authors, except for those for which authors have declared in advance the use of which is not allowed, however, compensation shall be paid according to the regulations, the author's name and the work's title shall be indicated, and other rights enjoyed by copyright owners according to this Law may not be infringed.

The provisions of the paragraph above shall be applicable to the restriction on the rights of publishers, performers, producers of sound recordings and visual recordings, radio stations and television stations.

(the obligation of copyright owner and publisher)The copyright owner shall deliver his work within the limit of time as contracted. The book publisher shall publish the book according to the publication quality and the limit of time as contracted.

A book publisher who fails to publish the work according to the limit of time as contracted shall bear civil responsibility according to the provisions of Article 54 of this Law.

In reprinting or republishing a work, the book publisher shall notify the copyright owner and pay to the copyright owner. If the publisher refuses to reprint or republish the work after its stock is exhausted, the copyright owner has the right to terminate the contract.

(the obligation of actor)In using a work of another for performance, the performer (performing individual or unit) shall acquire the license of the copyright owner and pay to the copyright owner. In organizing a performance, the organizer shall acquire the license of the copyright owner and pay to the copyright owner.

Performance of a work derived from adaptation, translation, annotation or arrangement of the preexistent work shall be in possession of the license of both the copyright owner of the work derived from adaptation, translation, annotation, arrangement or compilation and the copyright owner of the preexistent work and shall be subject to the payment of compensation.

(the obligation of the fabricator of recording)In using a work of another for making a sound or visual recording product, the sound or visual recording producer shall acquire the license of the copyright owner and pay to the copyright owner.

In using a work derived from adaptation, translation, annotation or arrangement of the preexistent work, the sound or visual recording producer shall acquire the license of both the copyright owner of the work derived from adaptation, translation, annotation or arrangement and the copyright owner of the preexistent work, and pay to the copyright owner.

In using a music work lawfully fixed by another as the sound recording work for making a sound recording product, the sound recording producer may be allowed to acquire no license from the copyright owner, however, he shall pay compensation according to the regulations; if the copyright owner has declared that the use of his work is not allowed, the work may not be used.

(the obligation of the fabricator of recording) In making a sound or visual recording product, the sound or visual recording producer shall conclude a contract with the performer and pay to the copyright owner.

(the rights of the fabricator of recording and the obligation of licensee) Sound or visual recording producers shall enjoy the right to license others to reproduce, distribute, lend and disseminate to the 
public through information networks and the right to get compensation in relation to sound or visual recording products they produced. Term of protection for the rights shall be 50 years and expires on December 31 of the fiftieth year after the product was first made.

In addition, the licensee who reproduces, distributes or disseminates to the public through information networks shall acquire the license of both the copyright owner and the performer and pay to the copyright owner.

(the broadcasting of unpublished works) In broadcasting an unpublished work of another, the radio or television station shall acquire the license of the copyright owner and pay to the copyright owner.

In broadcasting a published work of another, the radio or television station may be allowed to acquire no license from the copyright owner and pay to the copyright owner.

This article explains that you should pay for the works whether the work is published or not,but it's different from whether you get the permission from the copyright owner.This embody the legislative spirit,which respect the copyright owner's right's disposition of their own works. This is in accordance with the perspect of protecting the graduation thesis and dissertation.

In a word,the aim of statutory license is to encourage the spreading of works widely and it's in accordance with the foundation of protecting the creation of works and spreading of the works.Because the object of the permission are published works, we should confirn the presumption that the spreading of the works are in line with the willing of the copyright owner.It also sets up the institution of preserving the copyright owner's rights and it allows copyright owners forbidding others to use their works by declaration and the copyright owner must be paid by the users. Take a wide view of the working characteristics,there are many aspects involving fair use in library,but on the contrary,there are less aspects of legal permission use. We can't take things lightly in the future,and it should be paid to enough attention to avoid legal dispute. [8]

\section{Problems can be easily neglected in statutory license}

It's easy to master the restrictions of legal permission in libraries,but it's also hard to practice them.we are lack of books and operation experience in some questions like who can be paid for the compensation of legal permission,how to pay for the compensation,the way of paying for the compensation and the define of the compensation.These questions needs awaiting learning and mastering in the future.Only putting theory into practice can we accord with the style of Theory with Practice.

\section{University libraries should pay attention on the restrictions of compulsory license when protecting the creation of works and spreading}

Compulsory license means a system that people can use the work after applying and being authorized by the ministry based on some justifications in some circumstances and it's not necessary to get the copyright owner's permission but you have to pay for that.

The restrictions of compulsory license in libraries. The proposition of the coercing permission's foundation is to restrict the copyright owner's exclusive right and refuse other's reasonable and legitimate use,because it goes against creating excellent works and spreading widely.Because in China we don't regulate the coercing permission in the Copyright Law,we have joined Berne Convention and Universal Copyright Convention,so some regulations on the compulsory license in these conventions can also be referenced.It's enough for libraries to understand and master knowledge concerned for compulsory license.We will have rules to follow to deal with the same situation in fear of dealing with it at a loss. [9]

The restrictions of compulsory license in libraries. The proposition of the compulsory license's foundation is to restrict the copyright owner's exclusive right and refuse others'reasonable and legitimate use,because it goes against creating excellent works and spreading widely.Because in China we don't regulate the coercing permission in the Copyright Law, but we have joined Berne Convention and Universal Copyright Convention,so some regulations on the compulsory license in these 
convention can also be referenced.It's enough for libraries to understand and master knowledge concerned for compulsory license. We will have rules to follow to deal with the same situation in fear of dealing with it at a loss.

\section{University libraries should pay attention on the latest development and trend when protecting the creation of works and spreading}

There have two important modifications in the eleventh session of the thirteenth meeting of the NPC Standing Committee:one is to modifiy the Article 4:"In exercising copyright, no copyright owner may violate the Constitution and laws and infringe the public interests. State shall supervision and management the publication and propagation of the work in accordance with law",and the other is to add an article as the Article 26:"To the copyright pledge, the pledger and the pledge by the copyright administrative department to the State registration of the pledge" .Library should know that the copyright is as property right as pledging, which is the lastest development and achievement. [10]

The revision of the Copyright Law deleted the first item of article 4:work the publication or distribution of which is prohibited by law shall not be protected by this law, and at the same time, added

"State shall supervision and management the publication and propagation of the work in accordance with law."as the additional regulation. The author holds that the works created by authors independently should enjoy copyright and be protected by Cpoyright Law. This is also an advantage of spreading works.Some scholars holds that the Artical 4 of the old Copyright Law violated the copyright of international convention, Berne Convention, and the Agreement on Trade-Related Aspects of Intellectual Property Rights(TRIPSX for short).The revision reflects the observe the WTO's regulations for China and shows the attitude of protection of the copyright.So,It's really necessary for libraries to pay attention on the latest development and trends so that we can serve teachers and students better.

\section{References}

[1] Y.P.Yan.The influence of intellectual property law in document information work. Researches In Library Science. vol. 02, pp. 81-85, 2005.

[2] H.D.Wu. Intellectual property law (the sixth edition).Bei Jing: China University of Political Science and Law press,2012.

[3] B.X.Wang. The Effect of Three-Step Approach on the Fair Use of Libraries:Based on the 3rd Revision of Copyright Law.Library Journal. 2013(05)

[4] Z.W.Jian. An analysis of legal problems in the reader service work. Journal of Academic Library and Information Science. vol.22, pp.73-74, 2004.

[5] Y.L.Wang. Research on the Copyright of Digitalized Dissertations in Libraries.Information Studies:Theory \& Application.vol. 27, pp. 595-596, 2004.

[6] M.Li. Avoiding the copyright infringement disputes about the digitalized dissertations in libraries. Journal of Information.vol.10, pp. 125-127, 2004.

[7] Surely·Znzlaw. the Civil Law. Bei Jing: Chinese financial\&Economic Publishing House,2014.

[8] D.M.Yu and J.Yang.The Protect Measure of the Copyright Statutory License. Journal of Yunnan University Law Edition.vol.20, pp. 120, 2007(05).

[9] X.D.Jiang.Study on the compulsory license of library document resources.Information and Documentation Work.vol.03,pp.12,2001.

[10] Information on http://www.gov.cn/flfg/2010-02/26/content_1544458.htm 